\title{
ANALISIS PENERAPAN METODE TRANSPORTASI UNTUK MENENTUKAN BIAYA DISTRIBUSI BBM JENIS PREMIUM DAN SOLAR KE SPBU KOTA SORONG PADAPT. PERTAMINA (PERSERO) UNIT PEMASARAN VIII TERMINAL BBM SORONG
}

\author{
Agung Santosa ${ }^{1}$, Wisang Candra Bintari ${ }^{2}$ \\ ${ }^{I}$ Mahasiswa S-1 program studi teknik industri UM- Sorong. \\ ${ }^{2}$ Dosen pengajar program studi teknik industri UM- Sorong.
}

Diterima: 1 September 2017. Dipublikasikan: 1 Oktober 2017

\begin{abstract}
Abstrak
Penulisan tugas akhir ini mempunyai tujuan untuk mengefisiensikan biaya distribusi BBM jenis premium setelah menerapkan metode transportasi, untuk biaya distribusi BBM jenis solar setelah menerapkan metode transportasi dan untuk mengetahui selisih biaya distribusi kategori BBM jenis premium dan solar ke SPBU selama satu tahun setelah menerapkan metode transportasi dibandingkan dengan biaya yang diterapkan oleh perusahaan. Dalam penulisan tugas akhir ini penulis menggunakan 2 metode yaitu Studi Kepustakaan (Library Reseach), penelitian ini dilakukan sebagai pola teori dalam penulisan laporan, Studi Lapangan (Field Reseach), penelitian ini dilakukan dengan mengadakan observasi langsung pada PT.PERTAMINA UPMS VIII Terminal BBM Sorong yang berhubungan dengan objek penulisan. Setelah penulis melakukan penelitian pada PT.PERTAMINA UPMS VIII Terminal BBM Sorong dan memperoleh data-data yang dibutuhkan dalam menyelesaikan tugas akhir ini dan dilakukan perhitungan dan analisis data di dapatkan hasil sebagai berikut yaitu Biaya distribusi BBM yang diterapkan perusahaan untuk BBM jenis premium sebesar Rp.10,836,335,190.00 sedangkan dengan metode transportasi untuk BBM jenis premium sebesar Rp.10,804,957,500.00 jadi Biaya distribusi BBM dengan metode transportasi lebih efisien sebesar Rp.31,377,690.00 dan untuk BBM kategori jenis solar biaya distribusi yang di terapkan perusahaan sebesar Rp.11,190,191,870.00 biaya distribusi dengan metode transportasi sebesar Rp.11,151,613,500.00 jadi metode transportasi lebih efisien jika diterapkan untuk menentukan biaya distribusi BBM kategori solar ke SPBU di kota sorong sebesar Rp.38,578,370.00 dan total biaya yang diterapkan perusahaan sebesar Rp.22,026,527,060,00 sedangkan menggunakan metode transportasi adalah sebesar Rp.21,956,571,000.00 maka biaya distribusi efisien sebesar Rp.69,956,060,00.
\end{abstract}

Kata Kunci : biaya distribusi BBM, metode transportasi.

\section{PENDAHULUAN}

Berdirinya suatu perusahaan di tengahtengah kehidupan masyarakat mempunyai tujuan untuk menghasilkan suatu alat pemuas yang berupa barang dan jasa untuk memenuhi kebutuhan manusia. Eksistensi perusahaan tersebut bergantung pada tanggapan masyarakat terhadap produkproduk yang dihasilkan dan berkaitan dengan program pemasaran produk yang dilakukan perusahaan. Maka dari itu setiap perusahaan wajib melakukan kegiatan distribusi salah satunya PT.PERTAMINA (Persero) yang mendistribusikan produk berupa BBM jenis solar dan premium dimana dalam proses distribusi tersebut diperlukan suatu strategi yang tepat pada suatu tujuan tertentu guna untuk meminimasi biaya distribusi seminimal mungkin. Dari masalah diatas penulis menerapkan suatu metode transportasi guna meminimasi biaya distribusi BBM jenis premium dan solar ke SPBU kota sorong dengan asumsi biaya distribusi dari masingmasing.Tujuan Penelitian Untuk mengefisiensi biaya distribusi untuk BBM jenis Premium setelah menerapkan metode transportasi. Untuk mengefisiensi biaya distribusi untuk BBM jenis Solar setelah menerapkan metode transportasi. Untuk mengetahui selisih biaya distribusi untuk 
BBM jenis premium dan solar ke SPBU selama satu tahun setelah menerapkan metode teransportasi dibandingkan dengan biaya perusahaan.

\section{METODOLOGI PENELITIAN \\ Lokasi dan Waktu Penelitian}

Penelitian ini dilakukan di kota sorong tepatnya pada PT.PERTAMINA (persero) UPMS VIII TERMINAL BBM SORONG tepatnya pada bagian distribusi BBM jenis premium dan solar yang didistribusikan ke SPBU kota Sorong. Penelitian ini dilakukan selama 3 (tiga) bulan.

\section{Jenis dan Sumber Data}

Jenis dan sumber data yang digunakan dalam penulisan ini adalah sebagai berikut:

\section{Data primer}

Sumber data ini merupakan data yang diperoleh dengan jalan mengadakan pengamatan langsung pada obyek penelitian yang juga melalui wawancara dengan pihak yang berkompeten dibidangnya. data-data tersebut adalah data lokasi SPBU, jalur transportasi.

2. Data sekunder

Sumber data ini merupakan data yang diperoleh dari bahan dokumentasi dan laporan-laporan perusahaan yang bersangkutan dengan tugas akhir ini. Datadata sekunder adalah data permintaan dan penawaran BBM, biaya distribusi BBM, jarak transportasi dari sumber ke tempat tujuan.

3. Studi pustaka

Sumber data ini merupakan data yang diperoleh dari beberapa studi literatur seperti buku-buku panduan dan referensi yang ada hubungannya dengan distribusi serta metode yang diterapkan dalam tugas akhir ini. Data-data yang di ambil dari studi pustaka adalah teori-teori yang mendasari penelitian ini yang berada di bagian landasan teori.

\section{Pengumpulan Data}

Adapun data-data yang diperlukan adalah :

1. Biaya distribusi BBM jenis Premium dan Solar pada PT.PERTAMINA (Persero) UNIT PEMASARAN VIII TERMINAL BBM SORONG Ke SPBU yang ada di kota Sorong. Pengambilan data dengan cara interview secara langsung Operation Head dan data distribusi sumber dari bagian distribusi.

2. Jarak distribusi BBM jenis Premium dan Solar pada PT.PERTAMINA (Persero) UNIT PEMASARAN VIII TERMINAL BBM SORONG ke SPBU. Pengambilan data dengan cara interview secara langsung Operation Head dan data distribusi sumber dari bagian distribusi.

3. Data permintaan dan penawaran BBM serta jarak

dari masing-masing SPBU. Pengambilan data dengan cara interview secara langsung Operation Head dan data distribusi sumber dari bagian distribusi.

4. Volume BBM jenis premium dan solar yang di distribusikan ke SPBU ke kota sorong. pengambilan data dengan cara interview secara langsung Operation Head dan data distribusi sumber dari bagian distribusi.

\section{Pengolahan Data dan Analisa Data}

Langkah-langkah pengolahan dan analisa data adalah sebagai berikut :

1. Menentukan biaya distribusi BBM jenis Premium dan Solar pada PT.PERTAMINA (Persero) UPMS VIII TERMINAL BBM SORONG ke SPBU kota Sorong dengan menerapkan metode transportasi.

2. Menentukan biaya transportasi dengan acuan data volume distribusi BBM dan jarak dari sumber ke 
tempat tujuan pemasaran (SPBU) selama satu bulan.

3. Menghitung biaya distribusi dengan metode Least Cost dengan cara mebebankan pada biaya terkecil. Karena pada penelitian ini hanya ada satu sumber tapi banyak tujuan maka biaya di bebankan pada masing-masing kapasitas.

4. Dalam proses pengerjaan dalam pengolahan data penulis menggunakan bantuan program Microsoft excel.

5. Melakukan analisa terhadap data-data permintaan dan penawaran BBM jenis premium dan solar.
6. Menganalisa biaya distribusi BBM jenis premium dan solar sesudah dan sebelum menetapkan jalur distribusi BBM pada PT.PERTAMINA (Persero) UPMS VIII TERMINAL BBM SORONG ke SPBU kota Sorong.

\section{HASIL DAN PEMBAHASAN Pengumpulan data}

Berdasarkan hasil penelitian pada PT.PERTAMINA maka diperoleh data sebagai berikut :

Tabel 1. tabel laporan biaya distribusi BBM jenis solar dan premium.

\begin{tabular}{lccc}
\hline Bulan & $\begin{array}{c}\text { Premium } \\
(\mathbf{R p})\end{array}$ & $\begin{array}{l}\text { Solar } \\
(\mathbf{R p})\end{array}$ & $\begin{array}{l}\text { Total } \\
(\mathbf{R p})\end{array}$ \\
\hline $\mathbf{2 0 1 0}$ & & & \\
\hline Okt & $743,250,000$ & $733,895,000$ & $1,477,145,000$ \\
\hline Nov & $826,957,000$ & $834,390,570$ & $1,661,347,570$ \\
\hline Des & $908,350,000$ & $908,607,500$ & $1,816,957,500$ \\
\hline $\mathbf{2 0 1 1}$ & & & \\
\hline Jan & $920,175,000$ & $940,950,000$ & $1,861,125,000$ \\
\hline Feb & $917,350,050$ & $923,750,000$ & $1,841,100,050$ \\
\hline Mar & $938,350,750$ & $968,709,700$ & $1,907,060,450$ \\
\hline Apr & $908,550,750$ & $992,850,000$ & $1,901,400,750$ \\
\hline Mei & $891,650,050$ & $992,350,000$ & $1,884,000,050$ \\
\hline Jun & $921,750,050$ & $1,002,795,000$ & $1,924,545,050$ \\
\hline Jul & $925,750,050$ & $966,353,900$ & $1,892,103,950$ \\
\hline Ags & $968,550,750$ & $959,809,700$ & $1,928,360,450$ \\
\hline Sep & $965,650,740$ & $965,730,500$ & $1,931,381,240$ \\
\hline
\end{tabular}

Dari hasil penelitian bahwa metode transportasi yang digunakan pada PT.PERTAMINA (Persero) UNIT PEMASARAN VIII TERMINAL BBM SORONG ke SPBU yang ada di kota Sorong menggunakan metode kontrak/sewa alat transportasi dapat dilihat bahwa biaya pada table diatas yang dikeluarkan sangat besar, maka dari itu peneliti mencoba menerapkan sebuah metode transportasi dengan tujuan untuk meminimasi biaya distribusi BBM pada PT.PERTAMINA (Persero) UNIT PEMASARAN VIII TERMINAL BBM SORONG ke SPBU yang ada di kota Sorong.

\section{Pengolahan Data}

Dalam pengolahan data ini dilakukan dengan menggunakan metode transportasi yaitu menggunakan metode Least Cost untuk menentukan biaya Distribusi BBM jenis Premium dan Solar dari PT. PERTAMINA (Persero) UPMS VIII TERMINAL BBM SORONG ke beberapa tempat pemasaran yaitu SPBU khususnya yang berada di wilayah kota sorong. Langkah-langkahnya sbb :

Tabel 2.hasil perhitungan metode transportasi. 


\begin{tabular}{|c|c|c|c|}
\hline Periode & $\begin{array}{l}\text { Jenis } \\
\text { BBM }\end{array}$ & $\begin{array}{c}\text { Metode } \\
\text { Transportasi } \\
\text { (Rp.) }\end{array}$ & $\begin{array}{l}\text { Selisih } \\
\text { (Rp.jt) }\end{array}$ \\
\hline \multicolumn{4}{|l|}{2010} \\
\hline \multirow[t]{2}{*}{ Okt } & Premium & $742,182,500$ & $1,067.5$ \\
\hline & Solar & $732,437,500$ & $1,457.5$ \\
\hline \multirow[t]{2}{*}{ Nov } & Premium & $825,300,000$ & 1,657 \\
\hline & Solar & $832,535,000$ & $1,855.5$ \\
\hline \multirow[t]{2}{*}{ Des } & Premium & $906,300,000$ & 2,050 \\
\hline & Solar & $906,352,250$ & $2,255.2$ \\
\hline \multicolumn{4}{|l|}{2011} \\
\hline \multirow[t]{2}{*}{ Jan } & Premium & $917,142,500$ & $3,032.5$ \\
\hline & Solar & $937,640,000$ & 3,310 \\
\hline \multirow[t]{2}{*}{ Feb } & Premium & $914,522,500$ & $2,827.5$ \\
\hline & Solar & $920,621,250$ & $3,128.7$ \\
\hline \multirow[t]{2}{*}{ Mar } & Premium & $935,075,000$ & $3,275.7$ \\
\hline & Solar & $964,975,000$ & $3,734.7$ \\
\hline \multirow[t]{2}{*}{ Apr } & Premium & $906,527,500$ & $2,023.2$ \\
\hline & Solar & $988,926,250$ & $3,923.7$ \\
\hline \multirow[t]{2}{*}{ Mei } & Premium & $889,665,000$ & 1,985 \\
\hline & Solar & $988,532,500$ & 3.817 .5 \\
\hline \multirow[t]{2}{*}{ Jun } & Premium & $918,635,000$ & 3,115 \\
\hline & Solar & $998,348,750$ & $4,446.2$ \\
\hline \multirow[t]{2}{*}{ Jul } & Premium & $922,582,500$ & $3,167.5$ \\
\hline & Solar & $963,015,000$ & $3,338.9$ \\
\hline \multirow[t]{2}{*}{ Ags } & Premium & $965,030,000$ & $3,520.7$ \\
\hline & Solar & $956,235,000$ & $3,574.7$ \\
\hline \multirow[t]{2}{*}{ Sep } & Premium & $961,995,000$ & $3,655.7$ \\
\hline & Solar & $961,995,000$ & $3,735.5$ \\
\hline
\end{tabular}

Dari hasil perhitungan diatas maka dapat dilakukan perbandingan antara biaya distribusi BBM untuk kategori jenis premium dan solar yang diterapkan oleh perusahaan dengan biaya distribusi dengan menggunakan metode transportasi.

Tabel 3. Tabel perbandingan biaya distribusi BBM

\begin{tabular}{llccl}
\hline $\begin{array}{c}\text { Period } \\
\mathrm{e}\end{array}$ & \multicolumn{1}{c}{$\begin{array}{c}\text { Jenis } \\
\text { BBM }\end{array}$} & $\begin{array}{c}\text { Beruya } \\
\text { (Rp.) }\end{array}$ & $\begin{array}{c}\text { Metode } \\
\text { Transportasi } \\
(\mathrm{Rp} .)\end{array}$ & $\begin{array}{c}\text { Selisih } \\
(\mathrm{Rp} . \mathrm{jt})\end{array}$ \\
\hline 2010 & & & & \\
\hline Okt & Premium & $743,250,000$ & $742,182,500$ & $1,067.5$ \\
\hline & Solar & $733,895,000$ & $732,437,500$ & $1,457.5$ \\
\hline Nov & Premium & $826,957,000$ & $825,300,000$ & 1,657 \\
\hline & Solar & $834,390,570$ & $832,535,000$ & $1,855.5$ \\
\hline Des & Premium & $908,350,000$ & $906,300,000$ & 2,050 \\
\hline & Solar & $908,607,500$ & $906,352,250$ & $2,255.2$ \\
\hline 2011 & & & & \\
\hline Jan & Premium & $920,175,000$ & $917,142,500$ & $3,032.5$ \\
\hline & Solar & $940,950,000$ & $937,640,000$ & 3,310 \\
\hline Feb & Premium & $917,350,050$ & $914,522,500$ & $2,827.5$ \\
\hline & Solar & $923,750,000$ & $920,621,250$ & $3,128.7$ \\
\hline Mar & Premium & $938,350,750$ & $935,075,000$ & $3,275.7$ \\
\hline & Solar & $968,709,700$ & $964,975,000$ & $3,734.7$ \\
\hline Apr & Premium & $908,550,750$ & $906,527,500$ & $2,023.2$ \\
\hline & Solar & $992,850,000$ & $988,926,250$ & $3,923.7$ \\
\hline Mei & Premium & $891,650,050$ & $889,665,000$ & 1,985 \\
\hline & Solar & $992,350,000$ & $988,532,500$ & 3.817 .5 \\
\hline Jun & Premium & $921,750,050$ & $918,635,000$ & 3,115 \\
\hline & Solar & $1,002,795,000$ & $998,348,750$ & $4,446.2$ \\
\hline Jul & Premium & $925,750,050$ & $922,582,500$ & $3,167.5$ \\
\hline & Solar & $966,353,900$ & $963,015,000$ & $3,338.9$ \\
\hline Ags & Premium & $968,550,750$ & $965,030,000$ & $3,520.7$ \\
\hline & & & &
\end{tabular}




\begin{tabular}{lllll}
\hline & Solar & $959,809,700$ & $956,235,000$ & $3,574.7$ \\
\hline Sep & Premium & $965,650,740$ & $961,995,000$ & $3,655.7$ \\
\hline & Solar & $965,730,500$ & $961,995,000$ & $3,735.5$ \\
\hline
\end{tabular}

Dari hasil perhitungan diatas maka dapat dilakukan perbandingan antara biaya distribusi BBM untuk kategori jenis premium dan solar yang diterapkan oleh perusahaan dengan biaya distribusi dengan menggunakan metode transportasi.

\section{Grafik Biaya distribusi Premium}

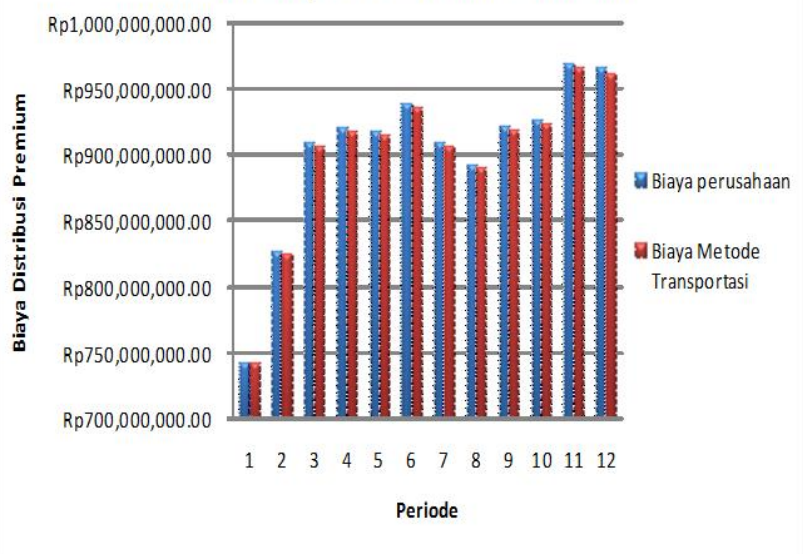

Gambar 1. Grafik biaya distribusi BBM jenis premium.

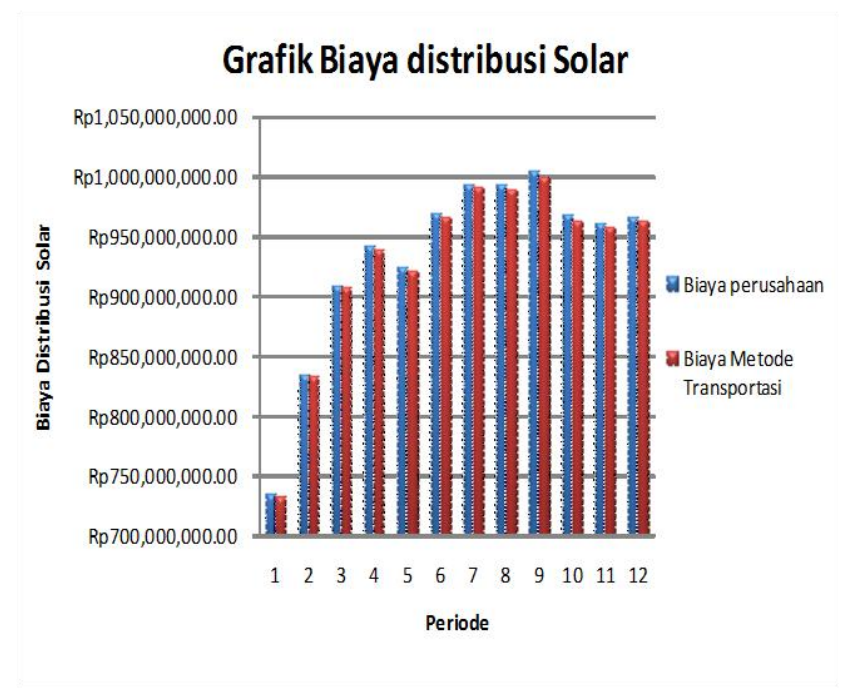

Gambar 2. Grafik biaya distribusi BBM jenis Solar.

\section{PENUTUP}

\section{A. Kesimpulan}

Berdasarkan dari pengumpulan dan pengolahan data maka diperoleh beberapa hasil penelitian yang penulis dapatkan yang mungkin dapat menjadi masukan-masukan pada PT.Pertamina (Persero) Unit pemasaran VIII Terminal BBM Sorong. Biaya distribusi BBM yang diterapkan perusahaan untuk kategori jenis premium sebesar Rp.10,836,335,190.00 sedangkan Biaya distribusi BBM dengan metode transportasi untuk kategori jenis premium sebesar Rp.10,804,957,500.00 jadi Biaya distribusi BBM dengan metode transportasi lebih efisien sebesar Rp.31,377,690.00 dan untuk BBM kategori jenis solar biaya distribusi yang di terapkan perusahaan sebesar Rp.11,190,191,870.00 biaya 
distribusi dengan metode transportasi sebesar Rp.11,151,613,500.00 jadi metode transportasi lebih efisien jika diterapkan untuk menentukan biaya distribusi BBM kategori solar ke SPBU di kota sorong sebesar Rp.38,578,370.00. berikut total selisih biaya distribusi BBM untuk kategori jenis premium dan solar yang perusahaan terapkan sebesar Rp.22,026,527,060.00 sedangkan menggunakan metode transportasi sebesar Rp.21,956,571,000.00 jadi selisih biaya yang perusahaan terapkan dengan metode transportasi sebesar Rp.69,956,060.00 maka dari itu menentukan biaya distribusi BBM ke SPBU yang ada di kota sorong lebih efisien jika menggunakan metode transportasi

\section{B. Saran}

Adapun saran yang penulis kemukakan sebagai suatu bahan pertimbangan bagi perusahaan adalah:

1. Diterapkannya metode transportasi untuk menentukan biaya distribusi sehingga bisa mengefisienkan biaya distribusi BBM ke SPBU.

2. Dibuatkannya sistem perawatan pada sarana dan fasilitas yang ada khususnya untuk sarana dan fasilitas penyaluran BBM secara berkala untuk menghindari kerusakan yang mendadak dan mengakibatkan berhentinya proses penyaluran BBM untuk sementara.

\section{DAFTAR PUSTAKA}

Kodrat, David Sukardi. 2010. Manajemen Distribusi. Yogyakarta: Graha Ilmu.

Noer, Bustanul Arifin. 2010. Riset Operasional. Yogyakarta: Andi Offset.

Ristono, Agus, Puryani. 2010. Penelitian Operasional Lanjut. Yogyakarta. Graha Ilmu.

Buku Panduan Suplai Dan Distribusi Bbm, Pertamina 2005

Buku Panduan K3ll \& Mm, Pertamina 2008

Http://Efisiensi-Biaya-DistribusiUksw.Html, 15.09.2011

Http://Tutorialkuliah.Blogspot.Com/2009 /11/Pengertian-SaluranDistribusi.Html, 20.10.2011

Http://Jurnal$\underline{\text { Sdm.Blogspot.Com/2009/11/Salura }}$
n-Distribusi-Definisi-Fungsi-

Dan.Html, 20.10.2011 
